\title{
Bacteriological Quality Assessment of Water Sold in Plastic Jerry cans within Katsina Metropolis, Katsina State, Nigeria.
}

\author{
Galadanchi Fatima A. ${ }^{1^{*}}$, Shamsuddeen Umar, ${ }^{2}$ Yusuf Buhari ${ }^{3}$, Abubakar Abdulazeez $^{4}$ \\ and Salisu Mansur Dabai ${ }^{5}$ \\ 1Department of Biological Sciences, Federal University Dutsinma, Katsina State \\ ${ }^{2}$ Department of Microbiology, Bayero University Kano \\ ${ }^{3}$ University of Chinese Academy of Sciences (UCAS), Beijing 100049, China \\ ${ }^{4}$ Department of Biotechnology, Nigeria Defense Academy \\ ${ }^{5}$ Department of Biological Sciences, Federal University Gusau \\ *Corresponding Author's Email Address: fateemahag@gmail.com; Tel: +2348066401994
}

\begin{abstract}
Water is the second most important compound after air for the sustenance of life on our planet. It is the most abundant molecule in living cells, essential for the proper functioning of cells. It is one of the cheap vehicles that transport gastro-intestinal diseases. Therefore, water for human consumption must be free from chemical substances and microbes that may cause disease in man. This study was carried out to determine bacteriological quality of water sold in jerry cans within Katsina metropolis. Twenty different water samples (Five each from Kofar kaura, Kofar marusa, Dakitara and Filin polo) were collected and transported to the laboratory for analyses. Temperature and $\mathrm{pH}$ values of each sample were measured accordingly. The samples were subjected to aerobic mesophilic bacterial count, Coliform count and detection of Escherichia coli. The result showed temperature values in the range of $23^{\circ} \mathrm{C}$ to $26^{\circ} \mathrm{C}$ while $\mathrm{pH}$ measurements were in the range of 6.9 to 7.3. Samples from Kofar kaura, Kofar marusa, Daki tara and Filin polo had mean bacterial counts of $1.718 \times 10^{6}, 1.052 \times 10^{6}, 2.042 \times 10^{6}$ and $1.612 \times 10^{6}$ colony forming units per milliliter (CFU/mL) respectively, and mean coliform counts of $25.2,122.6,77$ and $128 \mathrm{CFU} / \mathrm{mL}$ respectively. All samples from all the sampling points contained $E$. coli. The study stresses the need for environmental and personal hygiene by all water vendors. It is, however, recommended that water retailing by truck pushers be monitored and regulated to avoid the risk of a pointsource epidemic.
\end{abstract}

Key words: coliforms, water quality, bacteriological quality, water vendors, Katsina

\section{INTRODUCTION}

Water is an indispensable resource that all living beings need for survival. Unfortunately, water is also a good medium for transmission of diseases. Poor-quality water affects human health and plant growth (Tabor et. al., 2011). Bacteriological water quality is defined in terms of the absence or presence of indicator organisms. Drinking water does not cause an infectious disease if it is free from indicator organisms (WHO, 2011). Access to safe drinking water is one of the basic human rights and is extremely important for health. For a country to maintain optimal health and development there has to be a continuous supply of safe drinking water to its population (Miner et. al., 2016). However, most of the world's population lacks access to adequate and safe water (Tadesse et. al., 2010), with884 million people in the world lacking access to safe drinking water. Sub-Saharan Africa accounts for over one third of this number (Kassie and Hayelom, 2017).

In developing countries like Ethiopia, around $80 \%$ of all diseases are directly related to poor drinking water quality and unhygienic conditions (WHO, 2006). Understanding the quality of groundwater is the prerequisite for determining its suitability for domestic, agricultural and industrial purposes. Many factors will have to be taken into account before making comments on groundwater quality (Mostafa et. al., 2014). Safe drinking water is one of the basic necessities for human beings. However, billions of people in the world do not have access to safe drinking water, appropriate sanitation, and hygiene in developing countries (Wright and Gundry, 2004). The quality of drinking water is a powerful environmental determinant of health and continues to be the foundation for the prevention and control of waterborne diseases. 
Pathogenic microorganisms that are transmitted by water include bacteria, viruses, and protozoa. Most of the microorganisms transmitted by water usually grow in the human gastrointestinal tract and reach the outside environment through feces. Traditionally, the presence of coliform bacteria in drinking water has been seen as an indicator of fecal contamination through cross connection, inadequate treatment, or inability to maintain a disinfectant residual in the water distribution system (APHA, 1995). Coliform bacteria are regarded as belonging to the genera Escherichia, Citrobacter, Enterobacter, and Klebsiella. Although coliform organisms may not always be directly related to the presence of fecal contamination or pathogens in drinking water, the coliform test is still useful for monitoring microbial quality of treated piped water supplies (WHO, 1993). An exception is Escherichia coli, a thermo-tolerant coliform, and the most numerous of the total coliform group found in animal or human feces, rarely grows in the environment and is considered the most specific indicator of faecal contamination in drinking water (WHO, 2017). The presence of $E$. coli provides strong evidence of recent faecal contamination and is used to estimate disease (WHO, 2017). The count for $E$. coli as a microbial water quality indicator should be zero per $100 \mathrm{ml}$ water for drinking purpose (WHO, 2013).

The use of physicochemical and bacteriological parameters to assess water quality gives a good impression of the pollution status of a groundwater body (Vasanthavigar et. al., 2012) which help to assess the chemical status and pollution levels of the aquifer (Tank and Chandel, 2010). In many cases, rural residents use borehole or spring water for their domestic and drinking consumption without strict water quality monitoring (Amanial, 2015; Shigut et al., 2017). There are several variants of the faecal-oral pathways of water-borne disease transmission. These include contamination of drinking water catchments (e.g., by pathogens of faecal origin, i.e human or animal faeces), water within the distribution system, or stored household water as a result of unhygienic handling (WHO, 2017; Johannes and Leeuwen, 2016). Contamination canoccurasthe water is taken out of the storage container as hands and utensils may come into contact with the water (WHO, 2017). Current World Health Organization (WHO) guidelines for drinking water quality support efforts to ensure safe collection, treatment, and storage of drinking water. The absence of indicator organisms in drinking water indicates its bacteriological quality and does not pose health risk if consumed (WHO, 2013).

Simply improving the quality of drinking water source may not solve the problem because people can become infected with microorganisms through many other ways (Johnson et. al., 2016). Therefore, in addition to water improvements at the source (e.g. protected wells, hand-pump, spring and tap stands), improvements in hygiene and sanitation practices are also important to minimize the risk of waterborne diseases (Zvidzai et al., 2007). Government regulations and research has centered on microbial risk assessment and management in the water sector; however, application and interpretation of findings has been lacking (Prystajecky et. al., 2014). In this study, the bacteriological quality of water sold by truck pushers in Katsina metropolis has been assessed, with special emphasis on bacterial counts, $\mathrm{pH}$ and temperature.

\section{MATERIALS AND METHODS}

\section{Study area and collection of water sample}

This study was conducted in Katsina metropolis, Katsina State. Four different sampling points (Kofar kaura, Kofar marusa, Filin polo and Daki Tara) were used for the study. Twenty samples from different jerry-cans were collected for microbiological analysis, using sterile sampling bottles. The samples were immediately taken to the laboratory for analysis.

$\mathrm{pH}$ and Temperature Measurement

The $\mathrm{pH}$ wasmeasured using a $\mathrm{pH}$ meter, which was determined using standardized $\mathrm{pH}$ buffer solutionto calibrate the meter according to guidelines of the American public health association (APH, 1985). An electrode was inserted into the buffer to calibrate the meter before inserted into the water samples. Mercury-in-glassthermometer was inserted into the water to detect the temperature readings for all samples.

\section{MICROBIOLOGICAL ANALYSIS}

\section{Sample preparation and serial dilution}

Each water sample was serially diluted 10 -fold in a total volume of $10 \mathrm{~mL}$ using sterile distilled water. Briefly, $1 \mathrm{~mL}$ of undiluted sample was transferred to a tube containing $9 \mathrm{~mL}$ sterile distilled water and mixed thoroughly. The resulting dilution was labeled $10^{-1}$. OnemL of 10 1 dilution was also transferred to another tube containing $9 \mathrm{~mL}$ of sterile distilled water and mixed thoroughly, yielding the $10^{-2}$ dilution. This was repeated until $10^{-6}$ dilution factor was attained. 
Aerobic Mesophilic Bacterial Count

Molten nutrient agar plates were prepared in petri dishes according to manufacturer's instructions. 0.1 milliter from each prepared dilution tube was transferred into appropriately labeled petri-dish from $10^{-2}-10^{-6}$. The plates were incubated at $37^{\circ} \mathrm{C}$ for $24 \mathrm{hrs}$.

\section{Detection of Escherichia coli}

Eosin methylene Blue Agar was used for the detection of $E$. coli, which produced bluish black colony with green metallic sheen.

Presumptive coliform test

Total coliform and faecal coliform were enumerated in water samples by the most probable number (MPN) method (APHA, 2005). Coliform counts were obtained using the fivetube assay of the MPN technique. The presumptive coliform test was carried out using MacConkey broth. The first set of the five tubes had sterile $10 \mathrm{ml}$ double strength broth and the second and third sets had $10 \mathrm{ml}$ single strength broth. All the tubes contained a Durham tube before sterilization. Three sets of the tubes received 10,1 , and $0.1 \mathrm{ml}$ of water samples using sterile pipettes. The tubes were incubated at $37^{\circ} \mathrm{C}$ for $24-48$ hours for the estimation of total coliforms and at $44.5^{\circ} \mathrm{C}$ for faecal coliforms for 24-48 hours and then examined for acid and gas production. The colour change of the broth established acid production from reddish-purple to yellow, and gas production was checked for by entrapment of gas in the Durham tube. The MPN was then determined from the MPN table for the five sets of the tube (APHA, 2005).

\section{Confirmation test}

Confirmation test was carried out by transferring a loopful of culture from a positive tube of the presumptive test into a tube of Brilliant Green Lactose Bile (BGLB) broth with Durham tubes. The tubes were incubated at $37^{\circ} \mathrm{C}$ for $24-48$ hours for total coliform and $44.5^{\circ} \mathrm{C}$ for faecal coliforms and observed for gas production.

\section{Completed test}

The completed test was carried out by streaking a loopful of broth from a positive tube onto Eosine Methylene Blue (EMB) agar plate for pure colonies. The plates were incubated at $37^{\circ} \mathrm{C}$ for $24-48$ hours. Colonies developing on $E M B$ agar were further identified based on Gram's staining and some biochemical tests including indole production, methyl red, Voges-Proskauer, and citrate utilisation (IMViC) test.

\section{Detection of fecal coliforms}

The presence of faecal coliforms in the drinking water sample was detected by performing the Eijkman test. The MPN positive test broths were further processed for detection of faecal coliform or faecalE. coli by inoculating in Brilliant Green Lactose broth and Tryptone broth for indole test at $44.5^{\circ} \mathrm{C}$. The indole positive and gas formation in Brilliant Green Lactose broth and Tryptone broth at $44.5^{\circ} \mathrm{C}$ confirmed the faecal coliform.

\section{Data analysis}

Data analysis was carried out using GraphPad prism version 8.0.2 (GraphPad, San Diego, CA) by one-way analysis of variance using Tukey's multiple comparisons test at 0.05 significance level and 95\% confidence interval. Aerobic mesophilic bacterial counts were logtransformed prior to analysis.

\section{RESULTS}

From the results obtained, all the water samples possessed $\mathrm{pH}$ range from 6.9 to 7.3 and temperature range of $23^{\circ} \mathrm{C}$ to $26^{\circ} \mathrm{C}$ (table 2). There were mean Aerobic mesophilic bacterial counts of $1.718 \times 10^{6}, 1.052 \times 10^{6}, 2.042 \times 10^{6}$ and $1.612 \times 10^{6} \mathrm{CFU} / \mathrm{mL}$ across the four different sampling locations, with all the samples being positive for $E$. coli (table 1).

Table 1: Summary of quality indices recorded at the different sampling points

\begin{tabular}{|c|c|c|c|c|c|}
\hline \multirow[b]{2}{*}{$\begin{array}{l}\text { Sampling } \\
\text { points }\end{array}$} & \multicolumn{5}{|c|}{ Quality indices \pm SD $(N=5)^{\mathrm{a}}$} \\
\hline & $\mathrm{pH}$ & $\begin{array}{c}\text { Temperature } \\
\left({ }^{\circ} \mathrm{C}\right)\end{array}$ & $\operatorname{AMBC}\left(\times 10^{6}\right)^{b}$ & Coliform count & E. colic \\
\hline Kofar kaura & $7.198 \pm 0.14$ & $24.76 \pm 0.47$ & $1.718 \pm 0.44$ & $25.2 \pm 6.30$ & + \\
\hline Kofar marusa & $7.142 \pm 0.12$ & $24.24 \pm 0.05$ & $1.052 \pm 0.774$ & $122.6 \pm 233.51$ & + \\
\hline Daki tara & $6.914 \pm 0.25$ & $24.44 \pm 1.19$ & $2.042 \pm 0.45$ & $77 \pm 68.11$ & + \\
\hline Filin polo & $6.748 \pm 0.33$ & $24.98 \pm 0.62$ & $1.612 \pm 0.826$ & $128 \pm 150.78$ & + \\
\hline
\end{tabular}

SD, standard deviation; AMBC, aerobic mesophilic bacterial count.

a The results show the mean readings/counts from 5 samples for each sampling point.

b The AMBC and coliform count are shown in $\mathrm{CFU} / \mathrm{mL}$.

$c+$ indicates the presence of $E$. coli 
There seems to be no significant statistical differences in coliform and aerobic mesophilic bacterial counts as well as temperature readings across the various sampling points. However, a statistically significant difference in
$\mathrm{pH}$ ( $P=0.0275)$ was observed between Kofar kaura and Filin polo, with samples from Kofar kaura having relatively higher $\mathrm{pH}$ readings (figure
A. Coliform count

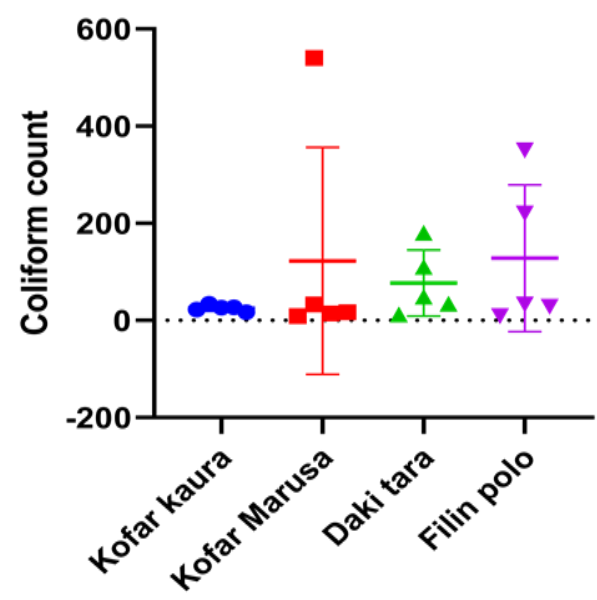

Sampling points

C. $\mathrm{pH}$ from different sampling points

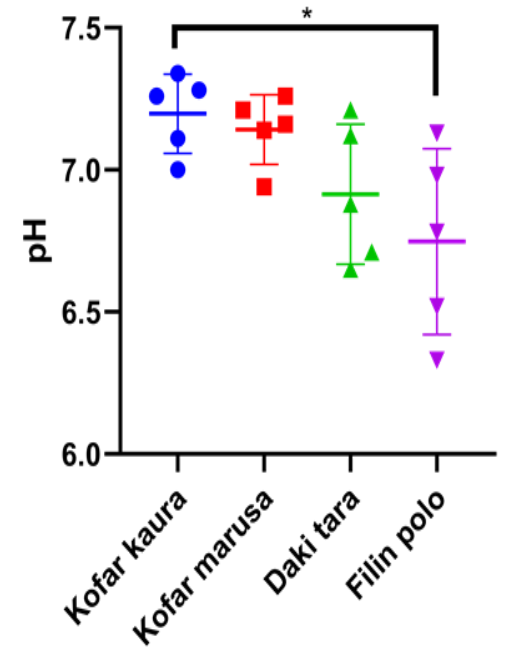

Sampling points
B. Aerobic mesophilic bacterial count (AMBC)

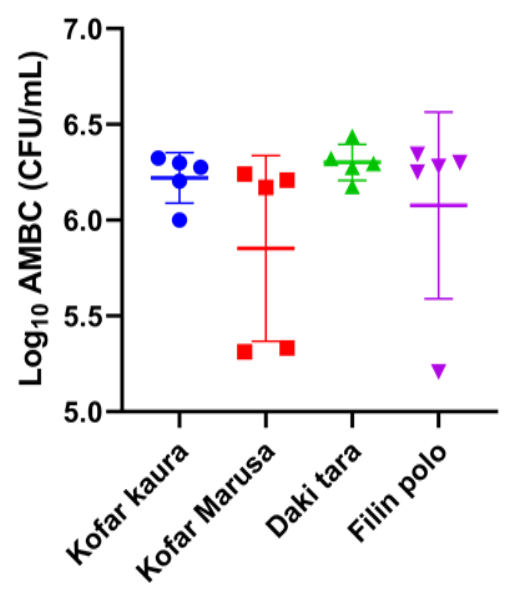

Sampling points

D. Temperature

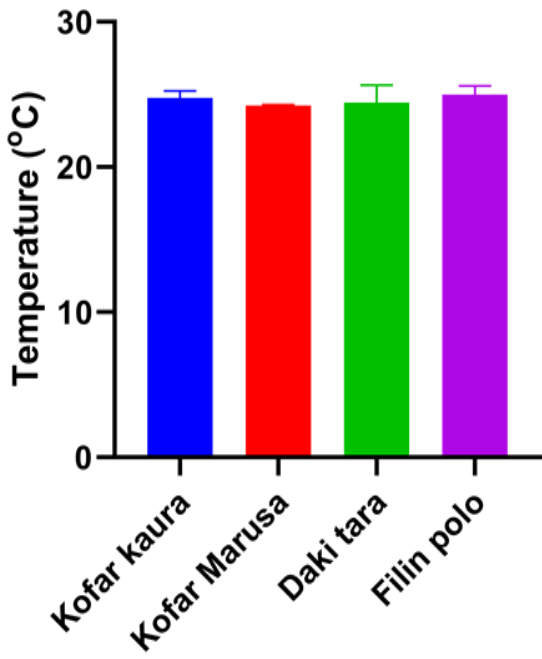

Sampling points

Figure 1: Quality indices as recorded at various sampling points 
Table 2: Results of $\mathrm{pH}$, temperature and bacteriological assessment of each sample

\begin{tabular}{|c|c|c|c|c|c|c|}
\hline \multirow[t]{2}{*}{ Sampling points } & \multirow{2}{*}{$\begin{array}{l}\text { Sample } \\
\text { ID }\end{array}$} & \multicolumn{5}{|c|}{ Quality indices } \\
\hline & & $\mathrm{pH}$ & Temperature & $\mathrm{AMBC}$ & $\log _{10} A M B C$ & $\begin{array}{c}\text { Coliform } \\
\text { count }\end{array}$ \\
\hline \multirow[t]{5}{*}{ Kofar kaura } & 1 & 7.26 & 24.1 & 1600000 & 6.20411998 & 34 \\
\hline & 2 & 7.28 & 25.3 & 2110000 & 6.32428246 & 27 \\
\hline & 3 & 7 & 24.7 & 1000000 & 6 & 22 \\
\hline & 4 & 7.11 & 25.1 & 1990000 & 6.29885308 & 26 \\
\hline & 5 & 7.34 & 24.6 & 1890000 & 6.2764618 & 17 \\
\hline \multirow[t]{5}{*}{ Kofar marusa } & 1 & 7.14 & 24.3 & 1480000 & 6.17026172 & 540 \\
\hline & 2 & 7.21 & 24.2 & 1620000 & 6.20951501 & 33 \\
\hline & 3 & 7.16 & 24.3 & 1740000 & 6.24054925 & 14 \\
\hline & 4 & 7.26 & 24.2 & 215000 & 5.33243846 & 17 \\
\hline & 5 & 6.94 & 24.2 & 205000 & 5.31175386 & 9 \\
\hline \multirow[t]{5}{*}{ Dakitara } & 1 & 7.21 & 23 & 1500000 & 6.17609126 & 110 \\
\hline & 2 & 6.88 & 25.1 & 2100000 & 6.32221929 & 34 \\
\hline & 3 & 6.71 & 26 & 1980000 & 6.29666519 & 12 \\
\hline & 4 & 6.65 & 23.6 & 2740000 & 6.43775056 & 180 \\
\hline & 5 & 7.12 & 24.5 & 1890000 & 6.2764618 & 49 \\
\hline \multirow[t]{5}{*}{ Filin polo } & 1 & 6.52 & 25 & 2000000 & 6.30103 & 33 \\
\hline & 2 & 6.33 & 25.8 & 161000 & 5.20682588 & 350 \\
\hline & 3 & 6.78 & 24.8 & 1780000 & 6.25042 & 9 \\
\hline & 4 & 7.13 & 25.2 & 1910000 & 6.28103337 & 28 \\
\hline & 5 & 6.98 & 24.1 & 2210000 & 6.34439227 & 220 \\
\hline
\end{tabular}

\section{DISCUSSION}

Water contamination predisposes human populations to the risk of disease transmission, especially gastrointestinal diseases, which remain a serious problem in developing countries. Most of the water-transmissible microorganisms, which include bacteria, viruses and protozoa, usually grow in the human gastrointestinal tract and are passed through the fecal-oral route. Endemic transmission of diseases through drinking water is evident in epidemiological and sero prevalence reports, which establishes evaluation of indicators as a basis for risk assessment (WHO and OECD, 2003).

It is also imperative that ideal thresholds of physicochemical parameters are maintained to ensure the integrity and safety of water for human consumption. For instance, previous reports have established a correlation between temperature and presence of microorganisms in water (Fransolet et. al., 1985; LeChavallier et. Though not always directly indicative of fecal contamination or presence of pathogenic UMYU Journal of Microbiology Research al., 1996; Giovani et. al., 2003). According to WHO and EPA, normal water $\mathrm{pH}$ ranges from 6.5 - 8.5 (WHO, 1996; EPA, 2003). The pH values recorded in this study range from $6.9-7.3$, suggesting that the water samples are acidic and slightly alkaline below the permissible limit recommended by WHO (1996). Temperature of the water samples is normal as recommended by EPA and NAFDAC. The $\mathrm{pH}$ and temperature results corroborate with a previous report (Garba, 2009), where the temperature is within the range and $\mathrm{pH}$ is acidic and slightly alkaline. Microbial indicators may not themselves be pathogenic but hint to potential microbiological quality of water. Coliform bacteria are regarded as those belonging to the genera Escherichia, Citrobacter, Enterobacter, and Klebsiella, and their presence in water is seen as an indicator of fecal contamination as well as inadequacy of treatment and failure to maintain residual disinfectant in the water distribution system (LeChavallier et. al., 1996). bacteria, coliform count remains useful in surveillance of water quality (WHO, 1993). 100 www.ujmr.umyu.edu.ng 
According to environmental protection agency (EPA), the total coliform count for all the samples examined in this study were higher than the acceptable counts of coliforms in water, which corroborates previous reports (Giovani et. al., 2003; Getachew et. al., 2019). The EPA maximum count for coliform bacteria in drinking water is zero per $100 \mathrm{ml}$ of water (EPA, 2003). The most probable number (MPN) per $100 \mathrm{ml}$ obtained for the water samples range from $9-540+$. This suggests that jerry can water samples have been contaminated by potentially dangerous microorganisms and are therefore not fit for drinking purpose. Presence of enteric coliforms especially $\mathrm{E}$. coli makes the water sample unsuitable for human consumption according to the guidance set by WHO for the evaluation of bacteriological quality of drinking water (WHO, 1996).

There is a wide preference for $E$. coli as indicator of fecal contamination as well as effectiveness of water treatment. The World Health Organization recommends that water used for human consumption should be free from microbial contamination, since the presence of $\mathrm{E}$. coli indicates a potential health risk for consumers (WHO, 2011). Because E. coli is more sensitive to disinfection than many pathogens, its detection, as it is with any coliform organism in treated water significantly demonstrates inefficacy of disinfection.

\section{REFERENCES}

Amanial, H. (2015). Assessment of physicochemical quality of spring water in Arbaminch, Ethiopia.Journal of Environmental Analytical Chemistry, 2, 2380-2391. 1000157. https://doi: 10.4172/2380-2391.1000157

American Public Health Association.Standard methods for examination of water and wastewater.19th ed. Washington (DC); 1995.

American Public Health Association-The American Water Works AssociationWater Environment Federation, 2005, Standard Methods for the Examination of Water and Wastewater (Washington, D.C.: APHA-AWWA-WEF).

APH (1985) Standard method for the examination of water and wastes $17^{\text {th }}$ Edition Washington DC 1325Pp.

Aroh KN, Eze EM, Ukaji D, Wachukwu CK, Gobo $A E$, Abbe SD, et al. Health and environmental components of sachet water consumption and trade in aba and Port Harcourt, Nigeria. Journal of Chemical Engineering and Materials Science. 2013;4(2):13-22
However, its absence alone does not indicate complete elimination of pathogens (WHO and OECD, 2003). To this end, with the presence of E. coli in all samples examined in this study, evidence of contamination is quite eminent, highlighting the potential danger posed by hawked water in the metropolis.

Mean aerobic mesophilic bacterial counts for all sampling points (table 1) exceed the recommended limit. This shows that the jerry cans contain high level of microbial contamination that makes water obtained from the jerry cans threatening to public health (Idakwo, 2004).

\section{CONCLUSION}

Microbial indicators are an important index of water contamination and judging by coliform and aerobic mesophilic bacterial counts in water samples analyzed in this study, hawked water in Katsina metropolis does not meet the standards for human consumption. This certainly warrants serious governmental efforts to ensure adequate supply of potable water and regulation of hawking by water vendors. In addition, coordinated efforts between government and health agencies is paramount in establishing awareness regarding the dangers associated with consumption of water sold in jerry cans.

C. Johannes and V. Leeuwen, "Water governance and the quality of water services in the city of Melbourne," Urban Water Journal, vol. 14, no. 3, 2016.

EPA (2003) US Environmental protection Agency safe drinking water Act EPA 816-F-03016.

Fransolet G, Villers G, Masschelein WJ. Influence of temperature on bacterial development in water. Ozone Science 1985;7:205-27

Garba I. (2009) Suitability of ground water various uses in Kano area Kano stateTechnical science Africana Journals Vol.4. 84-

$88 p$.

GetachewKabewMekonnen, BezatuMengistie, GeremewSahilu, WorkuMulat and Helmut Kloos.Determinants of microbiological quality of drinking water in refugee camps and host communities in Gambella Region, Ethiopia. Journal of Water, Sanitation and Hygiene for Development (2019) 9(4) 671-682. doi: 10.2166/washdev.2019.148 
GiovaniNogueira, Celso V Nakamura, Maria CB Tognim, Benício A Abreu Filho and Benedito P Dias Filho.Microbiological quality of drinking water of urban and rural communities, Brazil.Rev SaúdePública 2003;37(2):232-6.

Idakwo P.Y. and Abu, G.O: Distribution and Statistical analysis of Bacteria in Lake Alauln the Arid Northern Nigeria. Journal of Applied Sciences and Environmental Management2004;8(l):59.

J. Wright and S. Gundry, “Household drinking water in developing countries: a systematic review of microbiological contamination between source and point-of-use," Tropical Medicine and International Health, vol. 9, no.1, pp.106-117, 2004.

Johnson RC, Boni G, Amoukpo $H$, Barogui $Y$, Diez G, Agossadou D, Sopoh GE, Boko M. Microbiological quality assessment of drinking water in Lalo commune, Benin (West Africa). Journal of Water Resource and Protection. 2016;8:81622.

Kassie GG, Hayelom DH. Bacteriological quality of drinking water from source to point of use among rural communities of FartaWoreda in north west, Ethiopia. African journal of microbiology research. 2017;11(26):1069-74.

LeChavallier M W, Welch NJ, Smith DB. Fullscale studies of factors related to coliform regrowth in drinking water. Applied and Environmental Microbiology 1996;62:2201-21.

Miner CA, Dakhin AP, Al Z, Zaman M, Bimba J. Physical and Microbiological Quality of Drinking Water Sources in Gwafan Community, Plateau State,Nigeria. Pyrex Journal of Research in Environmental Studies. 2016;3(1):0016.

Mostafa, A. H., Al-Wasify, R. S., Sayed, A. M., \&Haroun, B. M. (2014).Microbiological and physicochemical evaluation of groundwater in Egypt.International Journal of Environment and Sustainability, 2(2).www.sciencetarget.com

Oludairo $\mathrm{O}$, Aiyedun J. Contamination of commercially packaged sachet water and the public health implications: An overview. Bangladesh Journal of Veterinary Medicine. 2016;13(2):73-81

Oyedeji O, Olutiola PO, Moninuola MA. Microbiological quality of packaged drinking water brands marketed in
Ibadan metropolis and Ile-Ife city in South Western Nigeria. African Journal of Microbiology Research. 2010;4(1):096-102

Prystajecky N, Cook C, Harris L, Dunn G. A comparative analysis of current microbial water quality risk assessment and management practices in British Columbia and Ontario, Canada.Science of the Total Environment. 2014;468469:544-52.

Shigut, D. A., Liknew, G., Irge, D. D., \& Ahmad, T. (2017). Assessment of physicochemical quality of borehole and spring water sources supplied to Robe Town, Oromia region, Ethiopia. Applied Water Science, $\quad 7(1)$, 155-164. https://doi.org/10.1007/ s13201-0160502-4

Tabor, M., Kibret, M., \&Abera, B. (2011). Bacteriological and physicochemical quality of drinking water and hygienesanitation practices of the consumers in Bahir Dar city, Ethiopia. Ethiopian Journal of Health Sciences, 21(1), 1926. https://doi.org/10.4314/ejhs. v21i1.69040

Tadesse D, Desta A, Geyid A, Girma W, Fisseha S, Schmoll O. Rapid assessment of drinking-water quality in the Federal Democratic Republic of Ethiopia: country report of the pilot project implementation in 2004-2005. Geneva: WHO/UNICEF; 2010.

Tank, D. K., \&Chandel, C. S. (2010). Analysis of the major ion constituents in groundwater of Jaipur city. Nature and Science, 8(10), 1-7.

Vasanthavigar ,M., Srinivasamoorthy, K., \&Prasanna, M. (2012). Evaluation of groundwater suitability for domestic, irrigational, and industrial purposes: A case study from Thirumanimuttar river basin, Tamilnadu, India. Environmental Monitoring and Assessment, 184(1), 405-420.

\section{https:// doi.org/10.1007/s10661-011-} 1977-y

WHO (2006). Guidelines for drinking water quality first addendum to (Vol. 1, Third ed.). Recommendations Geneva.

WHO, (1996). Guidance for drinking water quality volume 2: Health criteria and otherSupporting Information second edition, world Health Organization, Geneva.

WHO, Guidelines for Drinking-Water Quality, World Health Organization, Geneva, Switzerland, 4th edition, 2017. 
WHO, Household Water Treatment and Safe Storage, World Health Organization, Geneva, Switzerland, 2013.

WHO-World Health Organization.Guidelines for drinking-water quality, Geneva, Volume 1, WHO. 4th ed; 2011.

World Health Organization .Guidelines for drinking water quality.Geneva; 1993.

World Health Organization .Guidelines for drinkingwaterquality.Geneva; 1993.

World Health Organization and the Organization for Economic Cooperation and
Development (2003). Assessing microbial safety of drinking water: Improving approaches and methods. IWA publishing, London, UK (www.iwapublishing.com), ISBN 184339-036-1.

Zvidzai C, Mukutirwa T, Mundembe R, SitholeNiang I. Microbial community analysis of drinking water sources from rural areas of Zimbabwe. African Journal of Microbiology Research. 2007;1(6):1003. 